\title{
VITAMIN E AND CARCINOGENESIS
}

\author{
Yumiko Nitta
}

Data and Specimens Center of Atomic Bomb Disaster, Research Institute for Nuclear Medicine and Biology, Hiroshima University

\section{Kenji Kamiya}

Department of Pathology, Research Institute for Nuclear Medicine and Biology, Hiroshima University

\section{Kenjiro Yokoro}

Radiation Effects Research Foundation

\begin{abstract}
The role of vitamin $\mathrm{E}$ in carcinogenesis is reviewed. Epidemiologically, an inverse correlation between serum vitamin $E$ levels and cancer frequency has been shown in lung and gastrointestinal (except colon) cancers, but the inverse correlation is not conclusive in cancers of the uterine cervix, colon, and breast. Clinically, vitamin $\mathrm{E}$ is effective in inhibiting large intestinal neoplasms. Experimentally, vitamin $E$ inhibits skin, oral, liver, and lung carcinogenesis, however, vitamin $E$ enhances mammary and colon carcinogenesis. The inhibitory effect of vitamin $E$ on chemically induced carcinogenesis in some cancers may be due to the antioxidative action of vitamin $E$ that prevents the formation of carcinogenic products and protects target cells from DNA damage. In contrast, the carcinogenic effect of vitamin E has been demonstrated in the lung, liver, forestomach, and soft tissues, but the mechanism of this carcinogenesis is yet to be elucidated. (J Toxicol Pathol $7: 179 \sim 190,1994$ )
\end{abstract}

Key words : Antioxidants, Vitamin E, Carcinogens, Carcinogenicity tests, Free radical

\section{Introduction}

The role of vitamin $E$ as an antioxidative agent, preventing peroxidation of unsaturated fatty acids by scavenging lipophilic radicals within membranes, is widely recognized ${ }^{1,2}$. Vitamin E also possesses an immunomodulatory property which is similarly attributed to its antioxidative action ${ }^{3,4}$. Epidemiological and case control studies in humans revealed that vitamin $E$ prevented certain types of cancers. As a result, vitamin $E$ has been selected as an agent for cancer chemoprevention trials that are being planned or are already underway ${ }^{5-7}$. However, the mechanism of the prevention of some cancers by vitamin $E$ has

新田由美子 神谷研二 横路謙次郎

Accepted for publication : January 20, 1994

Mailing address: Yumiko Nitta, Data and Specimens Center of Atomic Bomb Disaster, Research Institute for Nuclear Medicine and Biology, Hiroshima University, Kasumi, 1-2-3, Minami-ku, Hiroshima 734, Japan. not been analysed.

Vitamin $\mathrm{E}$ was concluded to be a safe antioxidative food additive ${ }^{8,9}$ because it was neither mutagenic in Salmonella assay nor tumorigenic in carcinogenicity tests. However, the demonstration of the carcinogenicity of antioxidants such as butylated hydroxyanisole, butylated hydroxytoluene, caffeic acid, catechol and sesamol ${ }^{10-15}$ and the publication of reports that vitamin $E$ participated in carcinogenesis as a carcinogen ${ }^{16-20}$ have resulted in a reevaluation of the sefety of vitamin $E$ as a food additive.

In this paper, we review the role of vitamin $\mathrm{E}$ in human and experimental carcinogenesis.

\section{Modifying Effects of Vitamin $E$ in Carcinogenesis}

\section{Epidemiological studies}

Vitamin $\mathrm{E}$ is widely distributed in foods, but it is difficult to estimate the amount of consump- 
tion on the basis of dietary contents. Therefore, most of the epidemiological reports on this nutrient are based on the level of vitamin $E$ in serum samples, while only a few are based on intake levels of vitamin $E$ from food.

Studies on the correlation between serum vitamin $E$ level and cancer frequency, cancer risk and cancer mortality revealed inverse, positive or negative correlation. Paired comparisons between patients and controls showed significantly low vitamin $E$ levels in the sera of male patients with lung cancer ${ }^{21}$, female patients with uterine cervical dysplasia or cancer $^{22}$, patients with alimentary tract cancer ${ }^{23.24}$, patients with chronic atrophic gastritis ${ }^{25}$, patients with cancers not related to smoking $^{24}$, and patients with melanoma ${ }^{26}$. Serum vitamin $\mathrm{E}$ levels in breast cancer patients were lower than those in control patients, and this was explained to be consequence of diseases in general rather than a feature of cancer per $s e^{27}$.

In contrast, significantly higher levels of vitamin $E$ were noted in the serum of breast cancer patients than in that of controls ${ }^{28.29}$. One explanation for this positive relationship is that high levels of vitamin $E$ could enhance tumor cell proliferation by eliminating the oxygen radicals that exert a toxic effect on tumor cells. This was not likely, however, because vitamin $\mathrm{E}$ was distributed not in the neoplastic tissue but mainly in the accompanying adipose tissue as demonstrated by the analysis of alpha- and gamma- tocopherols in neoplastic and non-neoplastic breast tissues from the same patients ${ }^{30}$.

The serum vitamin E level showed no correlation with the frequency of colon, rectum, pancreas, skin, breast, prostate, bladder, or uterine cervical cancer $^{31-36}$.

The correlation between serum vitamin $\mathrm{E}$ level and cancer risk has been examined. Low serum levels of vitamin $E$ caused the risk of cancer to increase in the stomach $^{37}$, prostate ${ }^{37}$, and colorectum $^{38}$. While, a high serum vitamin $E$ level was protective for lung cancer ${ }^{39}$.

The serum vitamin E level correlated inversely to the mortality of colon cancer patients ${ }^{40}$, while it did not correlate to the mortality of stomach or large intestinal (except colon) cancer patients ${ }^{41}$.

An inverse correlation was observed between intake level of vitamin $E$ and frequency of lung cancers among nonsmokers ${ }^{42,43}$. Moreover, a high intake level of vitamin $E$ correlated to the reduction of risk in uterine cervical, pharyngeal, and oral cancer ${ }^{44,45}$, but it was not correlated to the reduction of risk in laryngeal cancer ${ }^{46}$.

\section{Clinical studies}

Various clinical trials have been performed to investigate the efficacy of vitamin $E$ as a chemopreventive agent $^{5-7}$. In a systemic screening program of commonly used prescription drugs, vitamin $E$ was found to be protective for cancers of all sites $^{47}$. In patients with familial adenomatous polyposis of the colon, the progression of lesion from polyp to adenoma was inhibited by the supplementation of vitamin $\mathrm{E}$, vitamin $\mathrm{C}$ and grain fiber ${ }^{48,49}$. After the complete removal of colorectal adenoma, vitamin E supplementation was effective in reducing abnormalities in cell kinetics, an indicator of the preneoplastic condition, in the $\operatorname{colon}^{50}$. Vitamin E supplementation was ineffective, however, in the regression of benign breast neoplasms ${ }^{51}$.

\section{Experimental Studies}

There are many reports on the modifying effects of vitamin $E$ on chemical carcinogenesis (Table 1). All of these studies were conducted with sythetic vitamin E, except three which used natural vitamin $E^{17,52,53}$.

\section{Skin cancer}

When $40 \mu \mathrm{mol}(17.2 \mathrm{mg})$ of vitamin E was applied topically to mice before initiation with 3.6 $\mu \mathrm{mol}$ of 7,12 -dimethylbenz(a)anthracene (DMBA), the frequency of skin papillomas did not decrease $^{53}$. However, when $1 \mathrm{mg}$ of vitamin $\mathrm{E}$ was applied to mice before initiation with $2.56 \mu \mathrm{g}$ of DMBA and promotion with $10 \mu \mathrm{g}$ of $12-O$ tetradecanoyl phorbol-13-acetate, the frequency of papillomas decreased ${ }^{54}$. Therefore, although vitamin $E$ was ineffective in inhibiting the tumorigenesis of the promotion component of DMBA, it was effective in inhibiting the tumorigenesis of the promotion component of 12-O-tetradecanoyl phorbol-13-acetate which stimulated the production of superoxide anion radicals and lipid hydroperoxides. The application of $1 \mathrm{mg}$ of vita- 
Table 1. Modifying Effects of Vitamin $E$ in Carcinogenesis

\begin{tabular}{|c|c|c|c|c|c|}
\hline Tissues & Species & Dose (Application) & Carcinogens & Effects & References \\
\hline skin & mouse & $17.2 \mathrm{mg}$ (p.o., single) & DMBA $(3.6 \mu \mathrm{M})$, selemium & no effect & 53 \\
\hline skin & mouse & $17.2 \mathrm{mg}$ (p.o., single) & DMBA $(3.6 \mu \mathrm{M}), \mathrm{GSH}$ & no effect & 53 \\
\hline skin & mouse & $17.2 \mathrm{mg}$ (p.o., 2/wk) & DMBA $(0.1 \mu \mathrm{M})$, selemium & enhance & 53 \\
\hline skin & mouse & $17.2 \mathrm{mg}$ (p.o., 2/wk) & DMBA $(0.1 \mu \mathrm{M}), \mathrm{GSH}$ & enhance & 53 \\
\hline skin & mouse & $17.2 \mathrm{mg}$ (p.o., 2/wk) & DMBA $(0.1 \mu \mathrm{M})$, TPA & inhibit & 53 \\
\hline skin & mouse & $17.2 \mathrm{mg}$ (p.o., 2/wk) & DMBA $(0.1 \mu \mathrm{M})$, TPA, selemium & inhibit & 53 \\
\hline skin & mouse & $17.2 \mathrm{mg}$ (p.o., 2/wk) & DMBA $(0.1 \mu \mathrm{M})$, TPA, GSH & inhibit & 53 \\
\hline skin & mouse & $17.2 \mathrm{mg}$ (p.o., 2/wk) & DMBA $(0.1 \mu \mathrm{M})$, TPA, mez, selemium & inhibit & 53 \\
\hline skin & mouse & $17.2 \mathrm{mg}$ (p.o., 2/wk) & DMBA $(0.1 \mu \mathrm{M})$, TKA, mez, GSH & inhibit & 53 \\
\hline skin & mouse & $1 \mathrm{mg}$ (p.o., single) & DMBA $(2.56 \mu \mathrm{M})$ & inhibit & 54 \\
\hline skin & mouse & 25 mg (p.o., 3/wk) & UV & inhibit & 55 \\
\hline oral & hamster & $10 \mathrm{mg}$ (paint, $2 /$ wk) & DMBA (19.5 mM) & inhibit & 57 \\
\hline oral & hamster & $10 \mathrm{mg}$ (p.o.,2/wk) & DMBA (3.9 mM) & inhibit & 58 \\
\hline oral & hamster & $250 \mu \mathrm{g}$ (inj., $2 / w \mathrm{k} \times 4)$ & DMBA-tumor & regress & 59 \\
\hline oral & hamster & $200 \mu \mathrm{g}($ p.o., $7 /$ wk $)$ & DMBA-tumor, $\beta$-carotene & regress & 60 \\
\hline liver & rat & $3.6,7.2,1.5 \mathrm{~g} / \mathrm{kg}$ diet & DEN $(200 \mathrm{mg} / \mathrm{kg} \mathrm{B}$. wt. $)+$ hepatectomy & inhibit & 63 \\
\hline liver & rat & $0.7 \mathrm{mg}$ (p.o., $20 \mathrm{kw}$ ) & AAF $(200 \mathrm{mg} / \mathrm{kg}$ diet $)$ & inhibit & 69 \\
\hline liver, forestomach & mouse & $50 \mathbf{g} / \mathbf{k g}$ diet & DEN (100 mg/l) & no effect & 17 \\
\hline liver & rat & $5 \mathrm{~g} / \mathrm{kg}$ diet & DEN ( $10 \mathrm{mg} / \mathrm{kg}$ B. wt.) & inhibit & 64 \\
\hline liver, pancreas & hamster & $10 \mathrm{~g} / \mathrm{kg}$ diet & DONDPA (20 mg/kg diet) & inhibit & 18 \\
\hline pancreas & rat & $0.6 \mathrm{~g} / \mathrm{kg}$ diet & azaserine & no effect & 72 \\
\hline pancreas & rat & $0.6 \mathrm{~g} / \mathrm{kg}$ diet & azaserine, selenium & inhibit & 72 \\
\hline mammary & rat & $1 \mathrm{~g} / \mathrm{kg}$ diet & DMBA (12 mg) & no effect & 76 \\
\hline mammary & rat & $1 \mathrm{~g} / \mathrm{kg}$ diet & DMBA (10 mg) & no effect & 73 \\
\hline mammary & rat & $1 \mathrm{~g} / \mathbf{k g}$ diet & DMBA (10 mg), selemium & inhibit & 73 \\
\hline mammary & rat & $5,10 \mathrm{~g} / \mathrm{kg}$ diet & DMBA ( $7.5 \mathrm{mg})$, selenium & inhibit & 74,75 \\
\hline mammary & rat & $225 \mathrm{IU} / 100 \mathrm{kal} \operatorname{diet}$ & MNU (25 mg/kg diet), vitamin A & no effect & 77 \\
\hline mammary & rat & $1.4 \mathrm{mg} / \mathrm{kg}$ diet & MNU (30 mg) & no effect & 78 \\
\hline mammary & rat & $1.4 \mathrm{mg} / \mathrm{kg}$ diet & MNU (30 mg) & enhance & 78 \\
\hline mammary & rat & $1.4 \mathrm{mg} / \mathrm{kg}$ diet & DMBA ( $50 \mathrm{mg}$ ) & no effect & 78 \\
\hline mammary & rat & $1.4 \mathrm{mg} / \mathrm{kg} \mathrm{diet}$ & DMBA (50 mg) & inhibit & 78 \\
\hline lung & mouse & $50 \mathrm{~g} / \mathrm{kg}$ diet & DEN (100 mg/l) & inhibit & 17 \\
\hline forestomach & mouse & $50 \mathrm{~g} / \mathrm{kg}$ diet & DON (100 mg/l) & no effect & 17 \\
\hline forestomach & mouse & $10 \mathrm{~g} / \mathrm{kg}$ diet & DMBA (46.8 mM) & no effect & 76 \\
\hline forestomach & rat & $10 \mathrm{~g} / \mathrm{kg}$ diet & BHA $(10 \mathrm{~g} / \mathrm{kg}$ diet $)$ & inhibit & 81 \\
\hline alimentary tract & mouse & $0.6 \mathrm{~g} / \mathrm{kg}$ diet & DMH (10 mg/kg B. wt.) & inhibit & 82 \\
\hline alimentary tract & mouse & $40 \mathrm{~g} / \mathrm{kg}$ diet & DHBNA (0.05\% d.w.) & no effect & 85 \\
\hline prostata & rat & $10 \mathrm{~g} / \mathbf{k g}$ diet & DMAB (50 mg/kg B. wt.) & no effect & 52 \\
\hline CNS, kidney & rat & $0.6 \mathrm{~g} / \mathrm{kg}$ diet & ENA ( $7.5 \mathrm{mg} / \mathrm{kg}$ B.wt. $)$ & no effect & 86 \\
\hline
\end{tabular}

Abbreviations used are; CNS : central nervous system ; p.o. : per os ; paint : painting ; inj. : injection ; DMBA : 7, 12-dimethybenz(a)anthracene; GSH : glutathione-S-transferase ; TPB : 12-O-tetradecanoylphorbol-13-acetate ; mez: mezerein ; UV : ultraviolet light; DEN : diethylnitrosamine; AAF : acethylaminofluorene ; DONDPA : 2, 2'-dioxiso-N-nitrosodipropylamine; MNU : N-methyl-N-nitrosourea ; BHA : butylated hydroxyanisole ; DMH : 1,2-dimethylhydrazine ; BHBNA : N-butyl-N-(4-hydroxybutyl)nitrosamine ; DMAB : 3, 2' -dimethyl-4-aminobiphenyl ; ENU : ethylnitrosourea ;

min E with $8.5 \mathrm{nmol}$ of $12-O$-tetradecanoyl phorbol-13 acetate two weeks after the application of $0.1 \mu \mathrm{mol}$ of DMBA did not reduce the frequency of papilloma, while the frequency of papilloma was reduced when the same dose of vitamin $E$ was applied with $8.5 \mathrm{nmol}$ of mezerein 20 weeks after the initiation with $0.1 \mathrm{~mol}$ of DMBA ${ }^{53}$. Mezerein was a tumor promoter and stimulated activity of ornithine decarboxylase in the target cells. In these experiments, vitamin E stimulated the activity of glutathione peroxidase and inhibited that of ornithine decarboxylase in the target cells ${ }^{53}$. Therefore, the anticarcinogenic activity of vitamin E might be operated through its ability to alter the 
enzymatic activities of target cells, and the activity might be linked to the glutathione-mediated protective system.

In ultraviolet-irradiated skin carcinogenesis, topical application of $25 \mathrm{mg}$ of vitamin $\mathrm{E}$ to mice throughout the experiment reduced the incidence of skin cancer from $81 \%$ to $42 \% 55$. Since the ultraviolet irradiation to mice stimulated the activity of epidermal ornitine decarboxylase ${ }^{56}$, this inhibition of skin cancer by vitamin $\mathrm{E}$ might operate through the reduction of the activity of this enzyme.

\section{Oral cancer}

When $10 \mathrm{mg}$ of vitamin $E$ and a $0.5 \%(w / v)$ of DMBA were applied to the buccal pouch of Syrian golden hamsters alternately for 16 weeks, the latency of epidermoid carcinoma was prolonged and the average size and number of the tumors were reduced ${ }^{57}$. When the concentration of DMBA solution was reduced to $0.1 \%(\mathrm{w} / \mathrm{v})$ the 10 $\mathrm{mg}$ of vitamin $\mathrm{E}$ completely prevented the development of tumors ${ }^{57,58}$. One possible mechanism of this prevention is that vitamin $E$ blocked the oxidation of DMBA to its ultimate carcinogen, the diol epoxide. When $250 \mu \mathrm{mol}(107.7 \mathrm{mg})$ of vitamin $\mathrm{E}$ was injected into the tumor-bearing buccal pouch twice weekly for 4 weeks, the average size of the tumors decreased ${ }^{59}$. Regression of the established tumors was also demonstrated by oral administration of vitamin $E$ at a dose of $400 \mu \mathrm{mol}$ $(172.3 \mathrm{mg})$ together with beta-carotene ${ }^{60,61}$. These findings indicated that vitamin $E$ stimulated the immunoreactive Langerhans cells of the buccal pouch and thereby facilitated the invasion of cytotoxic macrophages and $\mathrm{T}$ lymphocytes.

When $70 \mu \mathrm{mol}(30.1 \mathrm{mg})$ or $300 \mu \mathrm{mol}(129.2$ $\mathrm{mg}$ ) of vitamin $\mathrm{E}$ was introduced into tumor cells of oral squamous carcinoma lines by liposomes in vitro, $36 \%$ of the cells were killed ${ }^{61}$. However, the same doses of vitamin $\mathrm{E}$ introduced into normal cells did not exhibit any cytotoxicity ${ }^{61}$. The selective cytotoxic effects of vitamin $E$ were also observed in two human oral carcinoma cell lines, when $70 \mu \mathrm{mol}(30.1 \mathrm{mg})$ of vitamin $\mathrm{E}$ was added to the culture media ${ }^{62}$.

\section{Liver cancer}

The effects of vitamin $E$ on the development of enzyme-altered foci in rat liver were investigated. The induction of gamma-glutamyltranspeptidase-positive foci was inhibited in rats fed a diet containing $0.36,0.72$ and $1.5 \%(3.6,7.2$ and $15 \mathrm{~g} / \mathrm{kg}$ diet) vitamin $E$ given for 6 weeks after initiation by $200 \mathrm{mg}$ DEN per $\mathrm{kg}$ body weight plus partial hepatectomy ${ }^{63}$. In another report, newborn rats were given $10 \mathrm{mg}$ DEN per $\mathrm{kg}$ body weight and fed a diet containing $500 \mathrm{ppm}(50 \mathrm{mg} / \mathrm{kg}$ diet $)$ vitamin E. After 3 months, the volume of glutathione $S-$ transferase-positive foci had significantly decreased, but after 11 months, the number and size of the foci were not different from those of rats without the treatment of vitamin $\mathrm{E}^{64}$. In hamsters fed a diet containing $1 \%(10 \mathrm{~g} / \mathrm{kg}$ diet) vitamin $\mathrm{E}$ for 40 weeks after the administration of $2,2^{\prime}-$ dioxo-N-nitrosodipropylamine, vitamin $E$ reduced the final frequency of glutathione S-transferase-positive foci ${ }^{18}$

The level of hepatic glutathione-S-transferase increased when rats were given $0.025 \%(250 \mathrm{mg} / \mathrm{kg}$ diet) vitamin $E$ for one month ${ }^{65}$. And the activity of glutathione-S-transferase was induced in benzapyrene-initiated primary hepatocytes when 25 $\mu \mathrm{mol}(10.8 \mathrm{mg} / l)$ of vitamin $\mathrm{E}^{66}$ was added into their culture media, Whereas, it is not conclusive whether or not the dietary vitamin $E$ may suppress the hepatocarcinogenicity through glutathionemediated pathway. One report showed that glutathione was effective to prevent the aflatoxin $B_{1}$-initiated rat hepatocarcinogenesis ${ }^{67}$, while another showed no effect of glutathione for the $D E N$-initiated rat hepatocarcinogenesis ${ }^{68}$. When rats were given $0.7 \mathrm{mg}$ of vitamin $\mathrm{E}$ per day simultaneously with 2-acetylaminofluorene for 20 weeks, the concentrations of serum gammaglutamyltranspeptidase and hepatocellular UDPglucuronyl transferase were reduced ${ }^{69}$.

A decrease of hepatic vitamin $E$ caused the accumulation of lipid peroxides in hepatocytes. When rats were fed a diet which contained ethanol with the concentration of $7 \%(v / w)$, high levels of ethane, which is a measure of lipid peroxidation, were observed in hepatocytes. The concentration of ethane was reduced by the intraperitoneal injection of vitamin $\mathrm{E}(400 \mathrm{mg} / \mathrm{kg} \text { body weight })^{70}$. [4Chloro-6-(2, 3-xylidino) 2-pyrimidyl-thio] acetic acid could induce liver cancers in rats whose liver 
contained significantly low concentration of vita$\min \mathbf{E}^{71}$.

\section{Pancreatic cancer}

When Syrian golden hamsters were fed a diet containing $1 \%$ vitamin $\mathrm{E}(10 \mathrm{~g} / \mathrm{kg}$ diet $)$ for 40 weeks after the administration of $2,2^{\prime}$-dioxo-Nnitrosodipropylamine, the frequency of ductal hyperplasia was reduced ${ }^{18}$. In azaserine-induced carcinogenesis in rats, the supplementation of vitamin $\mathrm{E}(600 \mathrm{mg} / \mathrm{kg}$ diet $)$ for 69 weeks after initiation did not interfere in the growth of acinal neoplasia, while simultaneous supplementation of vitamin $E$ and selenium $(2.5 \mathrm{mg} / \mathrm{kg}$ diet) reduced the incidence of atypical nodule, adenoma and carcinoma $^{72}$.

\section{Mammary cancer}

The effect of vitamin $E$ and/or selenium supplimentation on DMBA-induced mammary carcinogenesis was investigated in rats $^{73-75}$. When both vitamin $\mathrm{E}(1,000 \mathrm{mg} / \mathrm{kg} \mathrm{diet})$ and selenium $(2.5 \mathrm{mg} / \mathrm{kg}$ diet $)$ were treated from 2 weeks before initiation by DMBA $(10 \mathrm{mg})$ throughout the experiment, the mammary tumor incidence was reduced, although supplementation of vitamin $E$ or selenium alone did not reduce the tumor incidences $^{73}$. The concentration of vitamin $\mathbf{E}$ in the supplemented diet $(1,090 \mathrm{mg} / \mathrm{kg}$ diet $)$ was 12.1 times higher than that in the control diet $(90 \mathrm{mg} /$ $\mathrm{kg}$ diet). The minimal amount of vitamin $E$ which was effective to reduce about $50 \%$ of DMBA (7.5 mg)-induced the mammary carcinomas was around $500 \mathrm{mg} / \mathrm{kg}$ diet with the supplement of selenium $(1 \mathrm{mg} / \mathrm{kg} \mathrm{diet})^{74.75}$. It was speculated that the suppression of lipid peroxidation by vitamin $\mathrm{E}$ along with the regulation of glutathione peroxidase by selenium was needed for the inhibition of mammary carcinogenesis. Whereas, the effects of vitamin $E$ on the immunomodulation, mitogen-induced blastogenesis and natural killer cytotoxicity were not conclusive ${ }^{75}$.

The treatment of vitamin $\mathrm{E}$ with the concentration of $0.01 \%$ of diet $(100 \mathrm{mg} / \mathrm{kg}$ diet $)$ was ineffective to inhibit the mammary tumor production by $\mathrm{DMBA}^{76}$, nor the treatment of vitamin $\mathrm{E}$ with the concentration of 10 times higher (225 IU $100 \mathrm{Kcal})$ than that of the control diet was effective for the inhibition of $\mathrm{N}$-methyl- $\mathrm{N}$-nitrosoureainduced rat mammary carcinogenesis ${ }^{77}$.
The effects of alpha-tocopherol and tocotrienol were investigated for DMBA and $\mathrm{N}$ methyl-N-nitrosourea induced mammary carcinogenesis in rats ${ }^{78}$. Administrations of alphatocopherol $\{3.349 \mu \mathrm{mol}(1.44 \mathrm{mg}) / \mathrm{kg}$ diet $\}$, the concentration of which was 28.9 times higher than that in the control diet, reduced neither the incidence nor the latency of mammary carcinomas induced by either DMBA or N-methyl-Nnitrosourea. Administration of tocotrienol at the same dose of alpha-tocopherol prolonged the latency of DMBA-induced mammary tumors, while the administration of tocotrienol increased tumor multiplicity of $\mathrm{N}$-methyl-N-nitrosoureainduced mammary tumors. Therefore, it was concluded that neither vitamin $E$ analog had a major impact on mammary tumor development after tumor induction with either DMBA or N-methyl$\mathrm{N}$-nitrosourea.

Studies on vitamin E deficiency in $\mathbf{N}$-methyl$\mathrm{N}$-nitrosourea-induced mammary carcinogenesis $^{79,80}$, meanwhile, revealed a shortened latency and increased tumor multiplicities in rats consuming a diet deficient in both vitamin $\mathrm{E}$ and selenium, although no alteration in tumorigenicity was observed by the deficiency of either vitamin $E$ or selenium alone.

Cancers in other sites

Rats fed a diet containing 1\% butylated hydroxyanisole per $\mathrm{kg}$ diet for 52 weeks developed hyperplasia at the prefundic and mid regions of the forestomach ${ }^{81}$. The incidence of hyperplasia at the prefundic region was lower in rats fed a diet containing $1 \%$ butylated hydroxyanisole plus $1 \%$ vitamin $\mathrm{E}(10 \mathrm{~g} / \mathrm{kg}$ diet $)$ than that in rats fed a diet containing $1 \%(\mathrm{w} / \mathrm{w})$ butylated hydroxyanisole alone $^{81}$. When mice were fed a vitamin $E$ supplemented diet $(10 \mathrm{~g} / \mathrm{kg}$ diet) and a control diet alternately up to 41 weeks this treatment showed no correlation to the incidence of forestomach tumors induced by $\mathrm{DMBA}^{76}$. In 1, 2-dimethylhydrazine-initiated carcinogenesis in mice, the administration of vitamin $E$ either suppressed ${ }^{82}$ or enhanced ${ }^{83}$ tumorigenicity in the lower intestinal tract. The influence of dietary vitamin $E$ deficiency to 1,2-dimethylhydrazine-induced intestinal tumors was investigted in rats ${ }^{84}$. When rats were fed a diet containing low level of vitamin 
E (less than $0.5 \mathrm{mg} / \mathrm{kg}$ diet) for $30-34$ weeks, the incidence of intestinal tumors was reduced ${ }^{84}$. When mice were fed a diet containing 5\% of vitamin $E(50 \mathrm{~g} / \mathrm{kg}$ diet $)$ for 2 years, the incidence of lung tumor initiated by DEN was reduced from $82.0 \%$ to $48.0 \%$ but that of the forestomach tumor was not reduced ${ }^{17}$.

When rats were given a diet containing $1 \%$ vitamin $\mathrm{E}(10 \mathrm{~g} / \mathrm{kg}$ diet) for 40 weeks, there was no effect with regard to the induction of urinary bladder cancer initiated by N-butyl-N-(4-hydroxy-butyl) nitrosamine ${ }^{85}$, and when they were fed a diet containing $1.5 \%$ vitamin $\mathrm{E}$ for 31 weeks, there was no effect with regard to the induction of prostate cancer initiated by 3,2'-dimethyl-4aminobiphenyl ${ }^{52}$.

In transplacental carcinogenesis, vitamin $\mathrm{E}$ was ineffective on the development of tumors in the nervous system and kidney by ethylnitrosourea ${ }^{86}$. In this experiment, the dose of vitamin $\mathrm{E}$ was $600 \mathrm{mg}$ per $\mathrm{kg}$ diet, and the duration of feeding was 18 monthts.

\section{Possible mechanisms}

Vitamin E could inhibit some forms of chemically induced carcinogenesis through its ability to alter the enzymatic activities of target cells, as noted in the skin $^{53,-55}$.

Injections of vitamin $\mathrm{E}$ immediately after the irradiation of ${ }^{60} \mathrm{Co}$ gamma-rays $(8.0 \mathrm{~Gy})$ to mice enhanced the 30 -day survival ${ }^{87}$. This was explained that the injection of vitamin $E$ might enhance immune response or recovery of bone marrow of the host.

The antioxidative action of vitamin $E$ could affect the inhibition of certain types of carcinogenesis. Vitamin $E$ inhibited the formation of nitrosamines, the major suspects for stomach cancer, by reducing the oxidation of nitric dioxide, nitric oxide and nitrite contained in foods in the stomach $^{88,89}$ and the formation of nitrosamines from atmospheric nitric dioxide in the skin $^{90}$. Epidemiologically, the average ratios of lipid peroxide/vitamin $E$ in the sera of cancer patients were significantly higher than those of normal controls $^{91}$. Vitamin E could also reduce the level of serum lipid peroxides in tumor-bearing mice ${ }^{91}$. Consequently, the frequency to subject target cells to carcinogenic compounds was reduced.

Administration of vitamin $E$ immediately after irradiation of ${ }^{60} \mathrm{Co}$ gamma-rays $(1.0 \mathrm{~Gy})$ to mice was effective to reduce the frequency of micronuclei in bone marrow cells ${ }^{92}$. This protective effect of vitamin $E$ was explained by the ability of vitamin $E$ to scavenge oxidizing free radicals. Actually, vitamin E protected liposomal membranes from lipid peroxidation induced by an $\mathbf{X}$ irradiation $(100 \mathrm{~Gy})^{93}$. Vitamin $\mathrm{E}$ inhibited the transformation of $\mathrm{C} 3 \mathrm{H} 10 \mathrm{~T} 1 / 2$ cells induced by $\mathrm{X}$ irradiation, benz(a)pyrene and tryptophan pyrolysate $^{94}$. Vitamin $\mathrm{E}$ also inhibited the sister chromatid exchanges of Chinese hamster ovary cells induced by the liberated free radicals from phagocytes ${ }^{95,96}$. Vitamin E protected the cells of lymphoblastoid lines and primary lymphocyte cultures from bleomycin-induced chromosomal breakage which was used as an indicator of genetic instability ${ }^{97}$. Thus, vitamin E reduced the concentration of free radicals, protected the chromosomes from the radicals and thereby might contribute to prevent the target cells from malignant transformation.

Salmonella mutagenesis assay was used to study the influence of vitamin $\mathrm{E}$ on the mutagenic activities of carcinogens. Vitamin $E$ did not affect the frequency of base-substitution mutations caused by $\mathrm{N}$-methyl-N'-nitro-N-nitrosoguanidine ${ }^{98}$ or aflatoxin $\mathrm{B}_{1}{ }^{99}$, nor the frequency of frameshift mutation caused by $\mathrm{N}$-acetoxy-2acetylaminofluorene ${ }^{98}$. Therefore, vitamin $\mathrm{E}$ does not seem to directly affect the repair of damaged DNA.

\section{Direct carcinogenic potential of vitamin $E$}

In acute and subchronic toxicity studies in Fischer 344 rats, oral administration of vitamin $E$ at the dose of $2 \mathrm{~g} / \mathrm{kg}$ body weight daily for 13 weeks significantly reduced body weight and survival and alveolar hyperplasia in the lung ${ }^{16}$. In a chronic toxicity study in CD rats, the oral administration of vitamin $\mathrm{E}$ at the dose of $2 \mathrm{~g} / \mathrm{kg}$ body weight daily for 104 weeks did not exert any influence on growth rate, survival or tumor incidence ${ }^{100}$. However, vitamin $\mathrm{E}$ families may be a contributive carcinogen in various organs when 
Table 2. Carcinogenic Potential of Vitamin E

\begin{tabular}{|c|c|c|c|c|c|}
\hline Vitamin $\mathbf{E}$ & Dose & Tissues & Species & Carcinogenicity & References \\
\hline d, 1 - $\alpha$-tocopheryl acetate & $2 \mathrm{~g} / \mathrm{kg} \mathrm{B.} \mathrm{wt.}$ & lung & rat & + & 16 \\
\hline natural vitamin $E^{11}$ & $50 \mathrm{~g} / \mathrm{kg}$ diet & liver & mouse & + & 17 \\
\hline natural vitamin $E$ & $50 \mathrm{~g} / \mathrm{kg}$ diet & lung & mouse & - & 17 \\
\hline natural vitamin $\mathrm{E}$ & $50 \mathrm{~g} / \mathrm{kg}$ diet & stomach & mouse & - & 17 \\
\hline d, $1-\alpha$-tocopheryl acetate & $10 \mathrm{~g} / \mathrm{kg}$ diet & stomach & hamster & + & 18 \\
\hline natural vitamin $\mathrm{E}$ & $20 \mathrm{mg}$ & subcutaneous & mouse & - & 19 \\
\hline natural vitamin $E+$ soya oil & $20 \mathrm{mg}+0.1 \mathrm{ml}$ & subcutaneous & mouse & + & 19 \\
\hline$d$ - $\alpha$-tocopherol & $16 \mathrm{mg}$ & subcutaneous & mouse & - & 20 \\
\hline$d$ - $\alpha$-tocopherol + soya oil & $16 \mathrm{mg}+0.1 \mathrm{ml}$ & subcutaneour & mouse & + & 20 \\
\hline d, $1-\alpha$-tocopheryl acetate & $40 \mathrm{mg}$ & subcutaneous & rat & + & 19 \\
\hline d, $1-\alpha$-tocopheryl acetate + soya oil & $40 \mathrm{mg}+0.2 \mathrm{ml}$ & subcutaneous & rat & + & 19 \\
\hline d, $1-\alpha$-tocopheryl acetate + soya oil & $20 \mathrm{mg}+0.1 \mathrm{ml}$ & subcutaneous & mouse & + & 19 \\
\hline
\end{tabular}

1): a mixture of natural tocopherols

it was given chronically and at sufficiently high amounts in animals (Table 2).

\section{Oral administration experiments}

Moore et al. reported the induction of squamous cells hyperplasia and papilloma by the vitamin E compound $d, l$-alpha-tocopheryl acetate in the forestomach of hamsters ${ }^{18}$. In this experiment, the $d, l$-alpha-tocopheryl acetate was mixed into a control diet at a concentration of $1 \%$ $(10 \mathrm{~g} / \mathrm{kg}$ diet). Nitta et al. reported that a $26 \%$ spontaneous liver tumor frequency was enhanced to $72 \%$ by the administration of natural vitamin $E$, that is, a mixture of natural tocopherols in C57BL/ $6 \mathrm{~N} \times \mathrm{C} 3 \mathrm{H} / \mathrm{He} \mathrm{Fl}$ mice $^{17}$. The concentration of this natural vitamin $\mathrm{E}$ in a diet was $5 \%(50 \mathrm{~g} / \mathrm{kg}$ diet), a dose about 700 times higher than that of vitamin $\mathrm{E}$ in the control diet.

\section{Injection experiments}

The carcinogenicity of vitamin $\mathrm{E}$ was demonstrated by subcutaneous injection experiments. The synthetic vitamin E compound, d, l-alphatocopheryl acetate induced soft tissue tumors, fibrosarcoma and malignant fibrous histiocytoma in one strain of rats and two strains of mice, when the agent was injected at doses of $40 \mathrm{mg}$ for rats and $20 \mathrm{mg}$ for mice subcutaneously once a week for 12 months $^{19}$. A naturally occurring vitamin $E$, that is, a mixture of natural tocopherols, did not induce tumors by the same procedure ${ }^{19}$, although it induced soft tissue tumors when injected subcutaneously together with vegetable oils $(0.2 \mathrm{ml}$ for rats and $0.1 \mathrm{ml}$ for mice) which were not carcinogenic by themselves ${ }^{19}$. Similarly, a natural alphatocopherol at the dose of $16 \mathrm{mg}$ per injection induced fibrosarcoma in a strain of mice when injected subcutaneously together with soya oil $(0.1 \mathrm{ml})$ for 10 months ${ }^{20}$. Neither the alpha-tocopherol nor the soya oil itself was effective for the induction of any tumors.

\section{Possible mechanisms}

It is helpful to difine vitamin $\mathrm{E}$ as either a tumor initiator, promoter, complate carcinogen, or progressive agent when discussing the mechanism of its carcinogenicity. Nitta et al. reported the increase in spontaneous liver tumor frequency by the administration of vitmain $E$ in a strain of mice genetically susceptible to liver carcinogens ${ }^{17}$. The genes affecting susceptibility to murine hepatocarcinogenesis controled the progression (tumor size) not the frequency of carcinogen-induced liver tumors $^{101}$. Therefore, this effect of vitamin $E$ could be placed under the category of tumor initiator.

Niwa et al. examined the expression of the $c$ $m y c$ gene in murine hepatocellular carcinoma and soft tissue tumors inuced by a vitamin $E^{102}$. An elevated expression and amplification of the gene was noted in the soft tissue tumors but not in the hepatocellular carcinomas $^{17,102,103}$. Since gene 
amplification occured after DNA damage ${ }^{103}$, it follows that repeated injections of vitamin $E$ caused DNA damage and triggered the amplification. This amplification might have contributed to the promotion or progression of malignancy in the soft tissue tumors.

\section{Summary}

Many epidemiological and clinical studies have been conducted on the role of vitamin $E$ in human cancers. Although the beneficial effects in many cases have not been conclusive, vitamin $\mathrm{E}$ exerted an inhibitory effect on cancer of the stomach $^{24,37}$, colon $^{40,48,49}$, lung $^{21,39,42,43}$, and uterine cervix ${ }^{44}$. These cancers have been demonstrated to require multiple gene-matations for their development ${ }^{104-108}$.

Many experimental studies have also been conducted on the role of vitamin $E$ in chemical carcinogenesis. The inhibitory Effect of vitamin $\mathrm{E}$ has been shown on skin, alimentary tract, liver, pancreas, mammary, lung, and prostate carcinogenesis. The involvement of the antioxidative action of vitamin $E$ for the inhibition of carcinogensis was strongly suggested in the skin ${ }^{90}$, stomach $^{88,89}$, mammary gland ${ }^{73-75}$, and some cell lines $^{94-97}$. In spite of this inhibitory effect of vitamin $E$ on chemical carcinogenesis, the direct carcinogenic potential of vitamin $E$ has been demonstrated in the forestomach ${ }^{18}$, liver ${ }^{17}$, and soft tissues ${ }^{19,20}$. However, the ultimate carcinogenic structure of the vitamin $E$ in this direct carcinogenesis remains to be elucidated.

Acknowledgements: We thank Dr. O. Niwa and Dr. A. Ito for reading the manuscript and Mr. Brain BurkeGaffney for his editorial assistance.

\section{References}

1. Packer, $\mathrm{L}$ : Protective role of vitamin $\mathrm{E}$ in biological systems. Am J Clin Nutr (Suppl) 53 : 1050-1055, 1991.

2. Bruton, $\mathrm{GW}$ and Ingold, $\mathrm{KU}$ : Vitamin $\mathrm{E}$ as an in vitro and in vivo antioxidant. Ann NY Acad Sci 570: 7-21, 1989.

3. Anderson, R and Theron, AJ : Physiological potential of ascorbate, beta-carotene and alpha-tocopherol individually and in combination in the prevention of tissue dysfunction mediated by phagocyte-derived reactive oxidants. World Rev Nutr Diet 62 : 27-58, 1990.

4. Tengerdy, RP : Vitamin E, Immune response, and disease resistance. Ann NY Aced Sci 570: 335344, 1989.

5. Costa, A, Santoro, G, and Assimakkopoulos, G : Cancer chemoprevention. Rev Oncol 3 : 657-663, 1990.

6. Bertram, JS, Kolonel, LN, and Meysken FL : Rationale and strategies for chemoprevention of cancer in humans. Cancer Res 47 : 3012-3031, 1987.

7. Malone, WF, Kelloff, GJ, Pierson, $H$, and Greenwald, P : Chemoprevention of bladder cancer. Cancer 60: 650-657, 1987.

8. Tomassi, $G$ and Silane, V : An assessment of the safety of tocopherols as food additives. Food Chem Toxicol 24: 1051-1061, 1986.

9. Blackett, $A D$ and Hall, DA : The effects of vitamin E on mouse fitness and survival. Gerontology 27 : 133-139, 1981.

10. Ito, N, Fukushima, S, Hagiwara, A, Shibata, M, Ogiso, T: Carcinogenicity of butylated hydroxyanisole in F344 rats. J Natl Cancer Inst 70 : 343352, 1983.

11. Hirose, M, Fukushima, S, Kurata, Y, Tsuda, H, and Tatematsu, M, Ito, $\mathbf{N}$ : Modification of N-methyl-N'nitro-N-nitrosiguanidine-induced forestmach and glandular stomach carcinogenesis by phenolic antioxidants in rats. $\mathrm{J}$ Natl Cancer Inst 70 : 343$352,1983$.

12. Hirose, M, Fukushima, S, Shirai, T, Hasegawa, R, Kato, T, Tanaka, H, Asakawa, E, and Ito, $\mathbf{N}$ : Stomach Carcinogenicity of caffeic acid, sesamol and cathecol in rats and mice. Jpn J Cancer Res 81 : 207-212, 1990.

13. Ito, $\mathbf{N}$ and Hirose, $\mathbf{M}$ : The role of antioxidants in chemical carcinogenesis. Jpn J Cancer Res 78 : 1011-1026, 1987.

14. Ito, N, Fukushima, S, Tsuda, H, Shirai, T, and Tatematsu, $\mathbf{M}$ : Studies on antioxidants : Their carcinogenic and modifying effects on chemical carcinogenesis. Food Chem Toxicol 24: 1071-1082, 1986.

15. Ito, $\mathbf{N}$ and Hirose, $\mathbf{M}$ : Antioxidants-Carcinogenic and chemopeventive propreties. Adv. Cancer Res 53 : 247-303, 1989.

16. Abdo, KM, Rao, G, and Montogomery, A : Thirteen-week toxicity study of d-alpha-tocopheryl acetate (vitamin E) in Fischer 344 rats. Food Chem Toxicol 24: 1043-1050, 1986.

17. Nitta, Y, Kamiya, K, Tanimoto, M, Kagimoto, $O$, Niwa, $\mathrm{O}$, and Yokoro, $\mathrm{K}$ : Effects of administration of natural vitamin $E$ on spontaneous hepatocarcinogenesis and $\mathbf{N}$-nitrosodiethylamine initiated tumors in mice. J Toxicol Pathol 4 : 55-61, 1991.

18. Moor, MA, Tsuda, H, Thamavit, W, Masui, T, and Ito, $\mathbf{N}$ : Differential modification of development of preneoplastic lesions in the Syrian golden hamster initiated with a single dose of 2, 2'-dioxo-Nnitrosodipropylamine: Influence of subsequent butylated hydroxyanisole, alpha-tocopherol, or car- 
bazole. J Natl Cancer Inst 78 : 289-293 ; 1987.

19. Nitta, Y, Kamiya, K, Tanimoto, M, Sadamoto, S, Niwa, $\mathrm{O}$, and Yokoro $\mathrm{K}$ : Induction of transplantable tumors by repeated subcutaneous injections of natural and synthetic vitamin $E$ in mice and rats. Jpn J Cancer Res 82: 511-517, 1991.

20. Constantinides, $\mathbf{P}$, and Harkey, $\mathbf{M}$ : Induction of a transplantable fibrosarcoma by the synergism of two non initiators, alpha-tocopherol and soya oil. Virchow Arch 405: 285-297, 1985.

21. Harris, RCM, Key, TJA, Silcocks, PB, Bull, D, and Wald, NJ : A case-control study of dietary carotene in men with lung cancer and in men with other epithelial cancers. Nutr Cancer 15: 63-68, 1991.

22. Palan, PR, Mikhail, MS, Basu, J, and Romney, SL : Plasma levels of antioxidant beta-carotene and alpha-tocopherol in uterine cervix dysplasias and cancer. Nutr Cancer 15 : 13-20, 1991.

23. Charpiot, P, Calaf, R, Di-Costanzo, J, Romette, J, Rotily, M, Durbec, JP, and Garcon, D : Vitamin A, vitamin $E$, retinol binding protein (RBP), and prealbumin in digestive cancers. Int $\mathrm{J}$ Vit Nutr Res 59 : 323-328, 1989.

24. Knekt, P, Aromaa, A, Maatela, J, Aaran, R-K, Nikkari, T, Hakama, M, Hakulinen, T, Peto, R, and Teppo, L : Vitamin E and cancer prevention. Am J Clin Nutr (suppl) 53 : 283-286, 1991.

25. Jaskiewicz, K, Van Helden, PD, Wild, IJF, Steenkamp, HJ, and Van Wyk, MJ : Chronic atrophic gastritis, gastric pH, nitrites and micronutrient levels in a population at risk for gastric carcinoma. Anticancer Res 10 : 833-836, 1990.

26. Knekt, P, Aromaa, A, Maatela, J, Alfthan, G, Aaran, R-K, Nikkari, T, Hakama, M, Hakulinen, T, and Teppo, $L$ : Serum micronutrients and risk of cancers of low incidence in Finland. Am J Epidemiol 134 : 3565-3561, 1991

27. Basu, TK, Hill, JB, Abdi, E, and Temple, N : Serum vitamin $A$ and $E$, beta-carotene, and selenium in patients with breast cancer. J Am Coll Nutr 8 : 524-528, 1989.

28. Gerber, M, Richardson, S, Paulet, PC, Pujol, H, and Paulet, AC: Relationship between vitamin $\mathrm{E}$ and polyunsatulated fatty acids in breast cancer. Cancer 64 : 2347-2353, 1989.

29. Gerber, M, Cavallo, F, Marubini, E, Richardson, S, Barbieri, A, Capiterri, E, Costa, A, Parlet, AC, Paulet, PC, Decarli, A, Pastorino, U, and Pujol, H : Liposoluble vitamins and lipid parameters in breast cancer : A joint study in northern Italy and southern France. Int J Cancer 42 : 489-494, 1988.

30. Langemann, H, Torhorst, L, Kabiersch, A, Krenger, W, and Honegger, CG : Quantitative determination of water- and lipid-soluble antioxidants in neoplastic and non-neoplastic human breast tissue. Int $\mathbf{J}$ Cancer 43: 1169-1173, 1989.

31. Potischman, N, Herrero, R, Briton, LA, Reeves WC, Stacewicz-Sapuntzakis, M, Jones, CJ, Brenes, MM, Tenorio, F, Britton, RC, and Gaitan, E: A casecontrol study of nutrient status and invasive cervical cancer. Am J Epidemiol 134: 1347-1355, 1991.
32. Hsing, AW, Comstock, GW, Abbey, H, and Polk, BF : Serologic precursors of cancer. Retinol, Carotenoids, and tocopherol and risk of prostate cancer. J Natl Cancer Inst 82 : 941-946, 1990.

33. Helzlsouer, KJ, Comstock, GW, and Morris, JS : Selenium, Lycopene, alpha-tocopherol, beta-carotene, retinol, and subsequent bladder cancer. Cancer Res 49 : 6144-6148, 1989.

34. Willett, WC, Polk, BF, Undewood, ABA, Stamper, MJ, Pressel, S, Posner, B, Taylor, JO, Schneider, K, and Hames, CG : Relation of vitamins $A$ and $E$ and carotenoids to the risk of cancer. N Engl J Med 310 : 430-434, 1984.

35. Connett, JE, Kuller, LH, Kjelsberg, MO, Polk, BF, Collins, G, Rider, A, and Hully, SB : Relationship between carotenoids and cancer. Cancer $64: 126-$ 134, 1989.

36. Comstock, GW, Bush, TL, and Helzisouer, K : Serum retinol, beta-carotene, vitamin $E$ and selenium as related to subsequent cancer of specific sites. Am J Epidemiol 135: 115-121, 1992.

37. Hakama, M, Aaran, RK, Alfthan, G, Aromaa, A, Hakulinen, P, Knekt, P, Maatela, G, Nikkari, T, Peto, R, and Teppo, L: Linkage of serum sample bank and cancer registry in epidemiological studies. Rec Prog Clin Biol Res 346: 169-178, 1990.

38. Longnecker, MP, Moreno, JM, Knekt, P, Nomura, Y, Schober, SE, Stahelin, HB, Wald, K, Gey, F, and Willett, WC: Serum alpha-tocopherol concentration in relation to subsequent colorectal cancer: Pooled data from five cohorts. J Natl Cancer Inst 84: 430-435, 1992.

39. Comstock, GW, Helzlsouer, KJ, and Bush, TL : Prediagnostic serum levels of carotenoids and vitamin $E$ as related to subsequent cancer in Washington County, Maryland. Am J Clin Nutr (Suppl) 53: 260-264, 1991.

40. Stahelin, HB, Rosel, F, Buess E, and Brubacher, G : Cancer, vitamins, and plasma lipids: prospective Basel study. J Natl Cancer Inst 73 : 1463-1468, 1984.

41. Stahelin, HB, Gey, KF, Eichhiozer, M, Ludin, E, Bernasconi, F, Thurneyses, J, and Brubacher, G : Plasma antioxidant vitamins and subsequent cancer mortality in the 12-year follow up of the prospective Basel study. Am J Epidemiol 133 : 766-775, 199 I.

42. Knekt, P, Jarvinen, R, Seppanen, R, Rissanen, A, Aromma, A, Heinonen, OP, Albanes, D, Heinonen, M, Pukkala, E, and Teppo, L : Dietary antioxidants and the risk of lung cancer. Am J Epidemiol 134 : 471-479, 1991.

43. Menkes, MS, Comstck, GW, Vuilleumire, JP, Helsing, KJ, Rider, AA, and Brookmeyer, R: Serum beta-carotene, vitamin $A$ and $E$, serenium, and the risk of lung cancer. N Engl J Med 315 : 1250-1254, 1986.

44. Vereault, R, Chu, J, Mandelson, M, and Shy, K : A case-control study of diet and invasive servical cancer. Int J Cancer 43 : 1050-1054, 1989.

45. Gridley, G, McLaughlin, JK, Block, G, Blot, WJ, Gluch, M, and Fraumeni, JF : Vitamin supplement 
use and reduced risk of oral and pharyngeal cancer. Am J Epidemiol 135 : 1083-1092, 1992.

46. Freudenheim, JL, Graham, S, Byers, TE, Marshall, JR, Haughey, BP, Swanson, MK, and Wilkinson, G : Diet, smoking, and alcohol in cancer of the larynx : A case-control study. Nutr Cancer 17: 33-45, 1992.

47. Friedman, GD and Selby, JV : Epidemiological screening for potentially carcinogenic drugs. Agents Actions (Suppl) 29 : 83-96, 1990.

48. DeCosse, JJ, Miller, HH, and Lesser, ML : Effect of wheat fiber and vitamin $C$ and $E$ on rectal polyps in patients with familial adenomatous polyposis. J Natl Cancer Inst 81 : 1290-1297, 1989.

49. Berenson, $\mathbf{M}$, Groshen, $\mathrm{S}$, Miller, $\mathrm{H}$, and DeCosse, J : Subject-reported compliance in a chemoprevention trial for familial adenomatous polyposis. J Behav Med 12 : 233-247, 1989.

50. Paganelli, GM, Biasco, G, Brandi, G, Santucci, R, Gizzi, G, Villani, V, Cianci, M, Miglioli, M, and Barbara, L : Effect of vitamin A, C, and $E$ supplementation on rectal cell proliferation in patients with colorectal adenomas. J Natl Cancer Inst 84 : 47-51, 1992.

51. Meyer, EC, Sommers, DeK, Reitu, CJ, and Mentis, $\mathrm{H}$ : Vitamin $\mathrm{E}$ and benign breast disease. Surgery 107 : 549-551, 1990.

52. Nakamura, A, Shirai, T, Takahashi, K, Ogawa, M, and Ito, $\mathbf{N}$ : Lack of modification by naturally occurring antioxidants of 3,2'-dimethyl-4-aminobiphenyl-initiated rat prostate carcinogenesis. Cancer Lett 58 : 241-246, 1991.

53. Perchellet, J-P, Abney, NL, Thomas, RM, Guislainm YL, and Perchellet, EM : Effects of combined treratments with selenium, glutathione, and vitamin $E$ on glutathione peroxidase activity, ornithine decarboxylase induction, and complete and multistage carcinogenesis in mouse skin. Cancer Res 47: 477$485,1987$.

54. Slaga, TJ and Bracken, WM : The effects of antioxidants on skin tumor initiation and aryl hydrocarbon hydroxylase. Cancer Res 37 : 1631-1635, 1977.

55. Gensler, $\mathrm{HL}$ and Magdaleno, $\mathrm{M}$ : Topical vitamin $\mathrm{E}$ inhibition of immunosuppression and tumorigenesis induced by ultraviolet irradiation. Nutr Cancer 15: 97-106, 1991.

56. Verma, AK, Lowe, NJ, and Boutwell, RK : Induction of mouse epidermal ornithine decarboxylase activity and DNA synthesis by ultraviolet light. Cancer Res 39 : 1035-1040, 1979.

57. Shklar, G: Oral mucosal carcinogenesis in hamsters : Inhibition by vitamin E. J Natl Cancer Inst 68: $791-797,1982$.

58. Trickler, D and Shklar, G : Prevention by vitamin $E$ of experimental oral carcinogenesis. J Natl Cancer Inst $78: 165-169,1987$.

59. Shklar, G, Schwartz, J, Tricker, DP, and Niukian, $\mathrm{K}$ : Pregression by vitamin E of experimental oral cancer. J Natl Cancer Inst 78 : 987-992, 1987.

60. Shkler, G, Schwartz, J, Trickler, D, and Reid, S : Regression of experimental cancer by oral adminis- tration of combined alpha-tocopherol and betacarotene. Nutr Cancer 12: 32I-325, 1989.

61. Schwartz, JL, Rajesh, P, Teicher, B, Wright, JE, Trites, DH, and Shklar, $\mathrm{G}$ : Induction of a $70 \mathrm{KD}$ protein associated with the selective cytotoxicity of beta-carotene in human epidermal carcinoma. Biochem Biophys Res Commum 169 : 941-946, 1990.

62. Schwartz, J and Shklar, G: The selective cytotoxic effect of carotenoids and alpha-tocopherol on human cancer cell lines in vitro. J Oral Maxillofac Surg 50: 367-373, 1992.

63. Ura, H, Denda, A, Yokose, Y, Tsutsumi, M, and Konishi, Y: Effect of vitamin $E$ on the induction and evolution of enzyme-alterd foci in the liver of rats treated with diethylnitrosamine. Carcinogenesis 8 : 1595-1600, 1987.

64. Hendrich, S, Duitsman, P, Kruger, SK, Jackson, A, and Myers, RK : Effects of alpha-tocopherol, phenobarbital, and butylated hydroxyanisole during promotion of diethylnitrosamine-induced rat hepatocarcinogenesis. Nut Cancer 15 : 53-62, 1991.

65. Ip, C, Clin, SF, Scimeca, JA, and Pariza, MW : Mammary cancer prevention by conjugated dienoic derivative of linoleic acid. Cancer Res 51 : 61186124, 1991.

66. Chen, HL, and Shiau, C-CA : Induction of glutathiono-S-transferase activity by antioxidants in hepatocyte culture. Anticancer Res 9: 1069-1072, 1989.

67. Novi, AM : Regression of aflatoxin $\mathbf{B}_{1}$-induced hepatocellular carcinomas by reduced glutathione. Science 212 : 541-542, 1980.

68. Ahluwalia, MB, Rotstein, J, Tatematsu HM, Roomi, MW, and Farber, E: Failure of glutathione to prevent liver cancer development in rats initiated with diethylnitrosamine in the resistant hepatocyte model. Carcinogenesis 4: 119-121, 1983.

69. Ngah, Z, Jarienm, Z, San, MM, Marzuki, A, Top, GM, Shamaan, NA, and Kadir, KA : Effect of tocotrienols on hepatocarcinogenesis induced by 2-acetylaminofluorene in rats. Am J Clin Nutr (Suppl) 53 : 1076-1081, 1991.

70. Mufti, S and Eskelson, CD : Alcohol-related cancers may be inhibited by dietary vitamin E. Ann NY Acad Sci 625 : 824-826, 1991.

71. Conway, JG, Tomaszewski, KE, Olson, MJ, Cattley, RC, Marsman, DS, and Popp, JA : Relationship of oxidative damage to the heppatpocarcinogenicity of the peroxisome proliferators di (2-ethylhexyl) phthalate and $W y-14643$. Carcinogenesis 10 : 513$519,1989$.

72. Appel, MJ, Roverts, G, and Woutersen, RA : Inhibitory effects of micronutrients on pancreatic carcinogenesis in azaserine-treated rats. Carcinogenesis 12 : 2157-2161, 1991.

73. Horvath, PM and Ip, C : Synergistic effect of vita$\min E$ and serenium in the chemoprevention of mammary carcinogenesis in rats. Cancer Res 43 : 5335-5341, 1983.

74. Ip, C : Feasibility of using lower doses of chemopreventive agents in a combination regimen for 
cancer protection. Cancer Lett $39: 239-246,1988$.

75. I $p_{2} \mathbf{C}$ and White, $\mathrm{G}$ : Mammary cancer chemoprevention by inorganic and organic selenium: single agent treatment or in combination with vitamin $E$ and their effects on in vitro immune functions. Carcinogenesis 8 : 1763-1766, 1987.

76. Wattenberg, LW : Inhibition of carcinogenic and toxic effects of polycyclic hydrocarbones by phenolic antioxidants and ethoxyquin. J Natl Cancer Inst 48: 1425-1430, 1972.

77. Beth, M, Berger MR, Aksoy, M, and Schmahl, D : Effects of vitamin A and E supplementation to diets containing two different fat levels on methylnitrosourea-induced mammary carcinogenesis in female SD-rats. Br J Cancer 56 : 445-449, 1987.

78. Gould, MN, Haag, JD, Kennan, WS, Tanner, MA, and Elson, CE: A comparison of tocopherol and tocotrienol for the chemoprevention of chemically induced rat mammary tumors. Am J Clin Nutr (Suppl) 53 : 1068-1070, 1991.

79. Tompson, $\mathbf{H J}$ : Effect of deficiencies of selenium and vitamin $\mathrm{E}$ alone or in combination on the induction of mammary carcinogenesis by 1-methyl-1nitrosourea. Carcinogenesis 12 : 2175-2179, 1991.

80. Takada, H, Hirooka, T, Hatano, T, Hamada, Y, and Yamamoto, $\mathrm{M}$ : Inhibition of 7,12-dimethylbenz (a) anthracene-induced lipid peroxidation and mammary tumor development in rats by vitamin $E$ in conjunction with selenium. Nutr Cancer 17 : 115122, 1992.

81. Hirose, M, Masuda, A, Tsuda, H, Uwagawa, S, and Ito, $\mathbf{N}$ : Enhancement of BHA-induced proliferative rat forestomach legion development by simultameous treatment with other antioxidants. Carcinogenesis 8: 1731-1735, 1987.

82. Cook, MG and McNamara, P : Effect of dietary vitamin $E$ on dimethylhydrazine-induced colonic tumors in mice. Cancer Res 40: 1329-1331, 1980.

83. Toth, $\mathbf{S}$ and Patil, $\mathrm{K}$ : Enhancing effect of vitamin $\mathbf{E}$ on murine intestinal tumorigenesis by 1,2-dimethylhydrazine dihydrochrolide. J Natl Cancer Inst 70 : 1107-1111, 1983.

84. McIntosh, GH : The influence of dietary vitamin $\mathrm{E}$ and calcium status on intestinal tumors in rats. Nutr Cancer 17 : 47-55, 1992.

85. Tamano, S, Fukushima, S, Shirai, T, Hirose, M, Ito, N : Modification by alpha-tocopherol, propyl galate and thertially butylhydroquinone of urinary bladder carcinogenesis in Fischer 344 rats pretreated with Nbutyl-N-(4-hydroxybutyl)nitrosamine. Cancer Lett 35 : 39-46, 1987.

86. Alexandrov, VA, Bespalov, VG, Boone, CW, Kellof, GJ, and Malone, WF : Study of postnatal effects of chemopreventive agents on offspring of ethynitrosourea-induced transplacental carcinogenesis in rats. I. Influence of retinol acetate, alphatocophetol acetate, thiamine chloride, sodium selenite, and alpha-difluoromethylornithine. Cancer Lett 60 : 177-184, 1991.

87. Malick, MA, Roy, RM, and Sternberg, J : Effect of vitamin $E$ on post irradiation death in mice. Exper- ientia 34 : 1216-1217, 1978.

88. Lathia, D and Blum, A : Role of vitamin E as nitrite scavenger and $\mathrm{N}$-nitrosoamine inhibitor: a review. Int. J Vit Nutr Res 9 : 430-438, 1989.

89. Mirvish, SS : Effects of vitamin $V$ and $E$ on $N$ nitroso compound formation, carcinogenesis and cancer. Cancer 58: 1842-1850, 1986.

90. Mirvish, SS, Mams, JP, and Issengerg, P : The nitrosation agent in mice exposed to nitrogen dioxide: improved extraction method and localization in the skin. Cancer Res 43 : 2550-2554, 1983.

91. Yang, K, Li, X, and Tsui, Z : The relationship between nutritional antioxidants and serum lipid peroxides in cancer patients. In Vivo $3: 211-214$, 1989.

92. Sarma, L and Kesavan, PC: Protective effects of vitamin $C$ and $E$ against gamma-ray-induced chromosomal damage in mouse. Int $\mathbf{J}$ Radiat Biol 63 : 759-764, 1993.

93. Konings, AWT, Damen, J, and Trieling, WB : Protection of liposomal lipids against radiation induced oxidative damage. Int J Radiat Biol 35 : 343-350, 1979.

94. Borek, C, Ong, A, Mason, H, Donahue, L, and Biagalow, JE: Selenium and vitamin $E$ inhibit radiogenic and chemically induced transformation in vitro via different mechaisms. Proc Natl Acad Sci USA 83 : 1490-1494, 1986.

95. Borek, C : Free-radical process in multistage carcinogenesis. Free Rad Res Comms 12-13 : 745$750,1991$.

96. Weitberg, AB : Effect of combinations of antioxidants on phagocyte-induced sister-chromachid exchanges. Mut Res 224 : 1-4, 1989.

97. Trizna, Z, Hsu, TC, and Schantz, SP : Protective effects of vitamin $E$ against bleomycin-induced genotoxicity in head and neck cancer ratients in vitro. Anticancer Res 12: 325-328, 1992.

98. Rosin, $M$ and Stich, HF : Assessment of the use of the Salmonella mutagenesis assay to determine the influence of antioxidants on carcinogenen-induced mutagenesis. Int J Cancer 23 : 722-729, 1979.

99. Whong, W-Z, Stewart, J, Brockman, HE, Ong, T-M : Comparative antimutagenicity of chlorophyllin and five other agents against aflatoxin $B_{1}$-induced reversion in Salumonella thyphimurium strain TA98. Teratog Carcinog Mutag 8 : 215-224, 1988.

100. Wheldon, GH, Bhatt, A, Keller, P, and Hummler, $\mathrm{H}: d, l$-alpha-tocopheryl acetate (vitamin E) : a long term toxicity and carcinogenicity study in rats. Int J Vit Nutr Res 53 : 287-296, 1983.

101. Dragani, TA, Manenti, G, and Della, PG : Quantitative analysis of genetic susceptibility to liver and lung carcinogenesis in mice. Cancer Res 51 : 6299$6303,1991$.

102. Niwa, O, Enoki, Y, and Yokoro, K : Overexpression and amplification of the $c-m y c$ gene in mouse tumors induced by chemicals and radiations. Jpn J Cancer Res 80 : 212-218, 1989.

103. Cole, MD: The myc oncogene: its role in transformation and differentiation. Ann Rev Genet 20 : 
361-384, 1986.

104. Fearon, ER, Cho, KR, Nigro, JM, Kern, SE, Simons, JW, Ruppert, JM, Hamilton, SR, Preisinger, AC, Thomas, G, Kinzler, KW, and Vogelstein, B : Identification of a chromosome $18 \mathrm{q}$ gene that is altered in colorectal cancers. Science $247: 49-56$, 1990.

105. Yokota, J, Wada, M, Shimosato, Y, erada, M, and Sugimura, T: Loss of heterozygosity on chromosomes 3,13 , and 17 in small-cell carcinoma and on chromosome 3 in adenocarcinoma of the lung. Proc Natl Acad Sci USA 84 : 9252-9256, 1987.

106. Tsuda, H, Hirohashi, S, Shimosato, Y, Tsugane, S, Yamamoto, H, Miyajima, $\mathbf{N}$, Toyoshima, $\mathbf{K}$, Yamamoto, T, Yokota, J, Yoshida, T, Sakamoto, H, Terada, $M$, and Sugimura, $T$ : No relation between long-term survival in breast cancer patients and amplification of two putative oncogenecoamplification units : hst $-1 /$ int -2 and $c-e r b B-2 /$ ear-1. Cancer Res 49: 3104-3108, 1989.

107. Yokota, J, Tsukada, Y, Nakajima, T, Gotoh, M, Shimosato, Y, Mori, N, Tsunokawa, Y, Sugimura, $T$, and Terada, $M$ : Loss of heterozygosity on the short arm of chromosome 3 in carcinoma of the uterine cervix. Cancer Res 49 : 3598-3601, 1989.

108. Hattori, Y, Odagiri, H, Nakatani, H, Miyagawa K, Naito, K, Sakamoto, H, Katoh, O, Yoshida, T, Sugimura, $T$, and Terada, $M: K$-sam, an amplified gene in stomach cancer, is a member of the heparinbinding growth factor receptor genes. Proc Natl Acad Sci USA 87 : 5983-5987, 1990. 